\title{
Clément Marot's initial visit to Lyon and Jeanne Gaillarde's Plume dorée: Announcing the French Renaissance in Verse (ca. 1524)
}

\section{Robert J. HUDSON}

Brigham Young University

\section{Introduction}

Traditional literary history reserves the honor of declaring the advent of the French Renaissance in verse to Pierre de Ronsard's Parisian "Brigade" of Pléiade poets, specifically to Joachim du Bellay's 1549 prose manifesto La Deffence, et illustration de la langue françoyse." This current essay seeks to read against this accepted historical notion, in locating the inauguration of French Renaissance poetics a quarter-century earlier and seeing it emerge from Clément Marot, the very figure that the Pléiade sought to disparage throughout $L a$ Deffence. ${ }^{2}$ A poet of an especially modest upbringing, raised in his maternal Languedoc and trained in versification by his father, royal poet Jean Marot, whom he followed into domestic service in the Valois court, Marot could claim neither an aristocratic pedigree nor did he aspire to the elevated registers and supercilious airs espoused by the Pléiade. Furthermore, due to his general Gallic irreverence and perceived evangelical leanings, his visits to Paris often lead to conflict with the Sorbonne or the guet (Paris' royal police) and ended in imprisonment or at least judicial pursuit. ${ }^{3}$ Rustic, even common, in tone and demeanor, Marot was nevertheless one of the earliest to translate Petrarch into French, the first to compose an original sonnet in the vernacular and, while cultivating the image of Maro Gallicus Ille 
(the Great French Virgil), likewise first translated a Virgilian eclogue and tried his poetic hand at the bucolic form, among other poetic innovations in French. ${ }^{4}$ In short, Marot had put into practice the vast majority of the supposedly revolutionary platforms of the opportunistic Pléiade some decades before Du Bellay's famous declaration.

All the same, the outwardly stated goal of glorifying France and the French language (the Illustration de la langue françoyse) through verse invention was shared by both Marot and the Pléiade; still, the sociology and internal politics of what constituted what we now term the Renaissance could scarcely be more different. In La création poétique au XVIe siècle, Henri Weber dedicates a chapter to "La condition sociale des poètes" and insists upon the requisite noble origins, or "tout au moins des prétentions à la noblesse" (73), of the Pléiade poets. ${ }^{5}$ Not only did the majority boast great wealth, the particle de to mark nobility and aristocratic ties to the crown, the Pléiade poets gravitated around the royal and Sorbonnic city of Paris and subscribed to the Neoplatonic theories of Marsilio Ficino and Pico della Mirandola that only further supported their ideas of poetic creation being reserved for a certain intellectual and social elite. ${ }^{6}$ On the contrary, Marot favored work and craftsmanship to divine inspiration, having been formed, to borrow a wonderful phrase from Thierry Montavani, "dans l'atelier du rhythmeur." Although certainly not noble, his attachment to the crown and the very person of the king was certainly much more direct than anyone in the Pléiade, given his duties as valet de chambre $d u r o i$ and that his travels generally followed those of the royal entourage - often keeping him at a safe distance from Paris. Furthermore, his approach to poetic creation was far more inclusive and required no prescriptive declaration or manifesto. For Marot, poetry was practical and performative, a rhetorical devise not a mystical rite.

What is "the Renaissance" but a condensed collection of reformative cultural practices adopted from Italy for which studia humanitatis and civitas - that is, a focus on the liberal arts and civic duty amid increased urbanization - are at the center? By its very nature, the Renaissance is inclusive and aimed at elevating and ennobling the bourgeois in an era of metropolitan embourgeoisement. This was achieved through practical education and, as Charles Nauert makes clear in his Humanism and the Culture of Renaissance Europe, "Poetry was indeed more practical than physics" (16). One of the major problems with the implementation of the Renaissance into France is that it crossed the Alps in the hands of an aristocratic social elite who had been inoculated in this new way of thinking during their diplomatic travels as part of the Valois campaigns in Italy. 
The result is an elitist cachet in Italianate Renaissance culture that is ever palpable in the theories of the Pléiade. Marot's Gallic contemporary François Rabelais is one of the few to realize this, which is why the education described in his Gargantua (1534) includes the "practical" elements of the liberal arts, physical education, poetry and, on rainy days, visits to local workshops and artisans to create social and civic cohesion (64-73). What's more, Rabelais' ideal institution of higher learning, the Thelemite Abbey with which the volume ends, includes both men and women "liberes, bien nez, bien instruictz" (149). ${ }^{8}$ Renaissance, indeed, goes hand-in-hand with Reformation - not only religious reform (with which Rabelais and Marot were certainly involved) but also social reform, i.e. inclusionary politics (women, bourgeois, the foreign other, etc.).

Of course, Rabelais published both Pantagruel (ca. 1532) and Gargantua (ca. 1534-35) in the city of Lyon, an urban center in the Renaissance celebrated for its four annual trade fairs that welcomed all of Europe, its cosmopolitanism, its vibrant intellectual scene, its print trade and, perhaps most importantly for this study, its open-mindedness (being at a safe distance from the Sorbonne) that permitted - even encouraged bourgeois and female participation in social exchange. ${ }^{9}$ Oft considered the second eye of France and antechamber of Italy, Lyon's welcoming climate helped establish it as an ideal royal retreat,${ }^{10}$ as well as a final stop in the kingdom for those leaving for Italy or a place of homecoming for those returning to France from abroad. Although no historical documentation has been found to ascertain this, it was most likely as part of the royal entourage that Clément Marot would find himself in Lyon around the year 1524. What does exist from this initial visit to the city is a pair of poems, two rondeaux exchanged between Marot and certain "Jeanne Gaillarde de Lyon, femme de grand savoir" (Defaux, I: 143-44; Rigolot, I: 140-41) that can stand in as Marot's Renaissance manifesto. ${ }^{11}$ In this rondeau - a poem adapted from a medieval Gallic form and crafted by a bourgeois poet with the aim of enabling and ennobling a learned woman - I contend, we find the distillation of the Renaissance spirit, the Rabelaisian quintessence, in verse. Likewise, in Jeanne's dignified response, there is a manifestation of civitas in education and social formation that aligns perfectly with the Renaissance ideal. In the pages below, I will analyze the two exchanged rondeaux, concluding with a later epigram also addressed to Jeanne Gaillarde, in aims to defend my thesis of Clément Marot announcing the Renaissance in verse ca. 1524 and decades before the Pléiade. 


\section{En donnant lieu à la main féminine: Marot and the Choice of the Rondeau (XIX)}

For many, including Du Bellay who famously urged Ronsard to adopt the Petrarchan form, the sonnet is the verse form of the Renaissance. "Sonne moy ces beaux Sonnetz" (II: 4,136 ) was the counsel the former offered in his Deffence to aspiring poets in the French vernacular, suggesting that they imitate Petrarch after having advised them to leave behind "toutes ces vieilles Poësies Françoyses [...]: comme Rondeaux, Ballades [...] et autres telles espisseries, qui corrumpent le goust de nostre Langue: et ne servent si non à porter temoignage de notre ignorance" (II: 4, 131-32). As noted above, Du Bellay's manifesto was a reaction to Thomas Sébillet's Art poétique français (1548), who had championed Marot. Concerning the Marotic rondeau, Sébillet offers some very interesting insights:

Car pource que la matière du Rondeau n'est autre que du sonnet ou épigramme, les Poètes de ce temps les plus friands ont quitté les Rondeaux à l'antiquité, pour s'arrêter aux Épigrammes et Sonnets, Poèmes de premier prix entre les petits. Et de fait tu lis peu de Rondeaux de Saint-Gelais, Scève, Salel, Héroët: et ceux de Marot sont plus exercises de jeunesse fondés sur l'imitation de son père, qu'œuvres de telle étoffe que sont ceux de son plus grand âge: par la maturité duquel tu trouveras peu de rondeaux crus dedans son jardin. (I: 3, 109)

To begin, Sébillet equates the brief, fixed form (entre les petits) of the rondeau with the sonnet and the epigram, suggesting that all three verse forms are viable for treating similar matters. However, by 1548 , four years after Marot's death and some twenty years since the poet had seriously pursued the rondeau, the form was outdated and had fallen out of vogue. (Many of the "older French" poets in whom Du Bellay would find redeeming qualities are listed here by Sébillet as well.) Even Marot's early rondeaux, Sébillet points out, mark a moment of transition between the grand rhétoriqueur traditions of his father and model Jean Marot. Still, since Marot's announcement came as early as 1524 , when his father was still alive and he was still supported by Marguerite d'Angloulême, what better way to announce the Renaissance in verse than taking up a tested verse form and exploiting it to new ends and to introduce new sensibilities and mentalities?

Beyond paying homage to his father and France's medieval past, as I have argued very recently elsewhere, ${ }^{12}$ implicit in Marot's choice of the rondeau is an affinity and familiarity with women. Both he and his father employed the form to the veneration and exaltation of womanhood 
during the period of their patronage by women of the royal court: Anne de Bretagne (1506-14) for Jean and Marguerite d'Angoulême (1519-27) for Clément. Also, unlike the Petrarchan sonnet, the superlative lyrical form in which the present desiring lyrical subject evokes a necessarily non-present desired object, ${ }^{13}$ the rondeau with its witty, varied takes on a refrain allows - even calls - for an exchange and interaction between men and women. This is certainly the case with the two rondeaux to be examined at present, whose complicity and conversation extend over two compositions.

From the outset of his sonnet dedicated to Jeanne Gaillarde, this woman of great learning, the nature of her Renaissance education is made clear:

D'avoir le pris en science et doctrine

Bien merita de Pisan la Cristine

Durant ses jours: mais ta plume dorée

D'elle seroit à present adorée,

S'elle vivoit par volunté divine.

Car tout ainsi que le feu l'or affine,

Le temps a faict nostre langue plus fine,

De qui tu as l'eloquence asseurée

D'avoir le pris.

Doncques, ma main, rends toy humble et benigne,

En donnant lieu à la main femenine:

N'escriptz plus rien en ryme mesurée

Fors que tu es une main bienheurée,

D'avoir touché celle qui est tant digne

D'avoir le pris. (XIX)

Not only has education endowed her with the gifts of science and doctrine, it has rendered her, an apparent bourgeoise (without the noble particle "de"), to level intellectual grounds with a celebrated medieval female model Christine de Pizan - whose own nobility is emphasized as Marot mentions her particle first: "de Pisan la Cristine" (v. 2). Equal learning is not all Jeanne merits, according to Marot, who sees the golden pen of his poetic addressee even worthy to be celebrated by Christine - as a sort of fulfillment of her proto-feminist Cité des dames - were she still on earth. One struggles to imagine higher praise that could be lavished on a middleclass woman than this: comparison with the greatest French woman of letters. Indeed, this gift of learning, Christine's legacy of which Jeanne 
is in possession, constitutes the rondeau's refrain ( $D^{\prime}$ avoir le pris) that carries over and takes on new valences in the other two stanzas.

If Renaissance learning was the focus of the first stanza, mastery and the embellishment of the French language (the primary concern of Du Bellay's Deffence) is at the heart of the second. Drawing parallels in a simile between the refiner's fire in goldsmithery (recalling, once more, Jeanne's plume dorée from the previous stanza) and the passage of time, during which we deduce Jeanne chastened her own grammar and rhetoric, Marot deems her eloquence and mastery as being as brilliant as the metallurgist's gold. Syllogistically, this leads to the "therefore moment," introduced by Marot with the "Doncques" that begins the final stanza, in which he surprisingly addresses his own poetic hand. The human hand, which would wield the golden pen of Jeanne/Christine as well as the goldsmith's hammer (recalling Marot's focus on praxis and craftsmanship), is evoked directly, as Marot invites his own to "rends toy humble et benigne, / En donnant lieu à la main femenine" (vv. 10-11). In its overwhelming joy (une main bienheurée) of being touched by hers, his hand - both physical and poetic - is resolute to abandon lyrical pursuits to make way for hers and her gift. The brute matter laboriously culled from the French earth (gangues of raw ore, language, his verse) through the gift of learning has been transformed and belongs in the worthy hand of the worthy woman who possesses the golden.

For Michèle Clément, this poem demonstrates "le rôle initiateur de Marot, en particulier à Lyon" (23) in announcing the emergence of female writers and giving room - both figuratively and literally, in his book (23) - for them to flourish. Not only does he call for reform in the literary realm, this rondeau also subtely appeals for change in language, social class, the literary canon and education - petitions to which Jeanne Gaillarde responds admirably in her own riposte to Marot, for which he gives actual printed place in his Adolescence under the title of "Réponse au précédent rondeau par ladite Jeanne Gaillarde" (XX).

\section{Her Golden Pen: Renaissance Civitas and Female Education in Rondeau XX}

Natalie Zemon Davis, in her essay "Women on Top" from Society and Culture, employs Rabelaisian/Bakhtinian terms to explain a woman's position at the beginning of the Renaissance: "The lower ruled the higher within the woman" (125). That is, a woman's womb and the believed hysteria produced by excessive cold and wet humors was thought to render her disorderly, fickle and unruly; her actions were dictated by the lower, 
carnal stratum and not the rational, intellectual upper. Davis, like Marot before her, is quick to cite Christine de Pizan as one of the first to turn this dichotomy on its head - beginning at the top. "Play with the exceptional woman-on-top," she argues, "[...] was also a resource for feminist reflection on women's capacities" (144). Jeanne Gaillarde was certainly one of these exceptional women, a representative of the main féminine through whom female poets may step into the space Marot offers them. However, as demonstrated by Jeanne's response, she understood the Bakhtinian need to ultimately reestablish societal hierarchies, all the while implicitly accepting the gilded pen of Christine bequeathed to her in rhyme.

Furthermore, in another article, "Women and the Crafts in SixteenthCentury Lyon," Davis points out that this bustling market city offered its women more opportunities than most cities in this era; however, there remained a great number of constraints (49). Women, still beholden to men and their households, were not to seek or find any glory in their artisanal or artistic creation (72). An awareness of this convention resonates in Jeanne's rondeau reply:

De m'acquiter je me trouve surprise

D'ung foible esprit, car à toy n'ay savoir

Correspondant: tu le peulx bien savoir,

Veu qu'en cest art plus qu'aultre l'on te prise.

Si fusse autant eloquente, et aprise,

Comme tu dys, je feroys mon devoir

De m'acquiter.

Si veulx prier la grace en toy comprise,

Et les vertus, qui tant te font valoir,

De prendre en gré l'affectueux vouloir,

Dont ignorance a rompu l'entreprinse

De m'acquiter. (XX)

From a purely formal standpoint, one notices that her rondeau features one fewer verse per stanza when compared to Marot's offering (Martin 91), simultaneously taking less of the printed space and thus presaging her refrain: "De m'acquiter" (to acquit/excuse herself from Marot's lofty praise and also to fulfill her end of a treaty). Throughout her response, she remains dismissive of praise and defers to Marot's stature as the poet of nobility. She admits finding herself taken aback (surprise, v.1), which very interestingly enjambs to alter the meaning of the word (surprise... / D'un foible esprit); not only is she surprised, she is "overtaken" by, a weak 
(female) spirit. Very interestingly, Christine de Pizan (who also composed rondeaux ${ }^{14}$ ) begins her Cité des Dames with a first-person female character finding herself bogged down in her attempts to dabble in a traditionally male intellectual domain:

One day, I was sitting in my study surrounded by many books of different kinds, for it has long been my habit to engage in the pursuit of knowledge. My mind had grown weary as I had spent the day struggling with the weighty tomes of various authors whom I had been studying for some time. I looked up from my book and decided that, for once, I would put aside these difficult texts and find instead something amusing and easy to read from the works of poets. (5) ${ }^{15}$

Christine, in her initial quest for knowledge and fickle diversion, discovers that all male authors "seem to speak with one voice and are unanimous in their view that female nature is wholly given up to vice" (6). However, Christine, aided by the Three Ladies, is able to create a text that initially seems to accept and then undercuts these very charges. Jeanne Gaillarde, in thus beginning her response, subversively accepts the comparison to Christine and continues her poetic reply. Not only does she, whom Marot labeled "femme de grand savoir," confess to lacking knowledge equal to his but she also admits to his being the greatest poet of his generation (en cest art plus qu'aultre l'on te prise, v. 4). All the while dismissive on the surface, in subtly accepting her comparison to Christine de Pizan and recognizing Marot's greatness, she also accepts the praise and the charge to create.

Her central stanza is composed of a single conditional compound (if... then) statement that further demonstrates her acceptance of Marot's offer, if only to fulfill her duty. Using the pluperfect subjunctive $S i$ (je) fusse... (v. 5), she admits that were she as eloquent and learned as Marot suggests she was, then she would use these talents to properly acquit herself - which she is already effectively accomplishing in composing the poem. The conclusive stanza also begins with $S i \ldots$; however, this time, it is neither conditional nor hypothetical but rather affirmative in nature. Indeed, she wishes to positively respond to his virtuous graciousness (Si veulx prier la grace en toy comprise / Et les vertus, qui tant te font valoir, vv. 8-9) and testifies to her heartfelt desire (l'affectueux vouloir) to do his bidding. And, in an ingenious third take on the phrase, at the conclusion of her beautifully composed rondeau, she moves from lack of knowledge (savoir) to pure ignorance, which has detracted her - as an unstable woman - from completing her undertaking (ignorance a rompu l'entreprinse, v. 11) to acquit herself. 
Jeanne Gaillarde was not the only aspiring female poet in Lyon during Marot's initial visit to the city nor was Marot alone in singing her praises. ${ }^{16}$ All the same, the grand Marot's singling her out in his work raises her as a standard to other female poets - who, judging from Martin's recent essay, responded to the charge, even if their works are regrettably lost (98). Lyon would, however, only have to wait a single generation later to see the fulfillment of Marot's announcement of the French Renaissance in verse in the flourishing of female poets within and around the so-called école lyonnaise.

\section{Clément Marot and Le Climat Lyonnois: Beyond 1524}

If he was already known and celebrated in Lyon from his initial visit to the city, by the time Marot's Adolescence clémentine was published in 1532, he was well established throughout France as the Prince des poëtes françois. Having replaced his late father as royal poet to François I, he had also remained in close contact, likely via correspondence and overlapping travels within the kingdom, with the intellectual circles of Lyon. The dedicatory epistle of his Adolescence clémentine, signed 2 August 1532 , is addressed "A un grand nombre de frères qu'il a: tous enfants d'Apollon" (I: 35), many of whom Lucien Febvre identifies as being members of the Lyonnais poetic circle who referred to themselves as the Sodalitium lugdunense (32-44). ${ }^{17}$ Despite the dedication to a number of frères, the group would expand by Marot's return to the city from exile in Italy in $1536,{ }^{18}$ by which time it included at least two female adherents, Claudine and Sybille Scève (sisters of the poet Maurice). ${ }^{19}$ Marot would be lavishly received and celebrated as a national (and civic) hero upon his 1536 return to Lyon and during subsequent visits to Lyon-based publisher Etienne Dolet to organize his complete works in 1538. His verse exchanges with the Scève sisters from this period and poems written for the Duchesse of Ferrara while in exile testify to his continued support of the improved status of women and of female poets. ${ }^{20}$ While it is unlikely that Marot ever returned to Lyon after 1538, he had already help foster a climate that allowed for female poets to compose and flourish in this humanistic center.

Lyon's poetic glory in the Renaissance is founded in the verse of the three poets who constitute the école lyonnaise: Maurice Scève, Pernette du Guillet and Louise Labé. Elsewhere, I have argued for the influence of Marot on Scève; ${ }^{21}$ however, what interests this essay are the vaguely Marotic prefaces included in the two female poets' works, which demonstrate both the persistence of Marot's charge to give place to women 
writers and proof of a new sensibility in Renaissance Lyon. To open Pernette du Guillet's posthumous 1545 Rymes, publisher Antoine du Moulin addresses himself "Aux Dames Lyonnaises" and uses his preface to make a positive example of the late poetess, inviting them to continue in her path of poetic creation:

(Ô) Dames Lyonnoises, pour vous laisser achever ce, qu'elle avoit si heureusement commencé: c'est à sçavoir de vous exerciter, comme elle à la vertu, et tellement, que, si par ce sien petit passetemps elle vous a monstré le chemin de bien, vous la puissiez si glorieusement ensuyvre, que la memoire de vous puisse testifier à la posterité de la docilité et vivacité de bons espritz, qu'en tous artz ce Climat Lyonnois a tousjours produict et tous sexes. (111) This open intellectual climate was one launched and brought to widespread attention by Marot and one that would prosper in Lyon for at least another decade beyond Pernette, when Labé would publish her Euvres in 1555. In her "Epistre dedicatoire," to fellow poetess Clémence de Bourges, the latter commends the unique present time "que les severs loix des hommes n'empeschent plus les femmes de s'apliquer aus sciences et disciplines" (17) and invites her, and her Lyonnais sisters alike, to leave their spindles and excel in public intellectual life, music, study, the sciences and letters (18).

The golden age of Renaissance Lyon - its humanistic printers, intellectual freedoms, women writers, etc. - would come to a screeching halt with the advent of the French Religious Wars and the installment of a rigorous, intransigent Calvinism in Lyon, ca. 1560 (Geisendorf 152-54). ${ }^{22}$ Ironically, 1560 was also the year in which the poetic glory of Ronsard, the newly minted Prince des poètes français, would be cemented with the publication and proliferation of his (Euvres. All the same, neither Calvin nor Ronsard (or Malherbe and Boileau after them) could stop the social progress set into motion by Christine, Rabelais, Marot, Labé and others.

$* * *$

In reconfiguring the French Renaissance, a necessary first step is to recognize the ideals of civitas implicit in the Italian model that was imported into France. Humanism and social reform may well have arrived via aristocratic diplomats who warped these ideas according to their limited feudal worldview. However, the earliest pens of the French Renaissance in literature insist on a more widespread and inclusive idea of reform, one that would call into question education, philosophy, the status of women, the possibility of bourgeois achievement, religious practice, 
etc. The intricately sculpted tufa stone used to create the majestic palaces of the Loire Valley is certainly a stunning testament to achievement and ideals of beauty at the highest reaches of the Renaissance. Still, the more lasting effects of the Renaissance, or Early Modern period, is its modernity: its focus on individuals and opportunity, the capacity of all mankind and the need foster a society where all could live, co-exist and strive in a constantly urbanizing world. Lyon was a supreme model of this new order and Marot the ideal literary mouthpiece to announce this change in climate to the Francophone world.

The Renaissance remains concerned with philology, rediscovery, learning, debate and creation. A translator of Ovid, Virgil and Petrarch, Marot did not diverge from that element of the Renaissance. Still, he recognized that humankind and matters of the mind exceed the dusty artifacts we so readily yield as signs of intellect and progress. In his final poem to Jeanne Gaillarde from his initial visit to Lyon, a dizain epigram, Marot emphasizes the divinity of the individual and the conquest of the mind over the ruins of societies past:

C'est ung grant cas veoir le Mont Pelyon,

C'est un merveille avoir veu la grant Troye:

Mais qui ne voyt la ville de Lyon,

Aulcun soulas à ses yeulx il n'octroye;

Non qu'en Lyon si grant plaisir je croye,

Mais bien en une estant dedans sa garde:

Car qui la voit en esprit si gaillarde,

Plaisir y prend plus qu'à veoir Ilion;

Et de ce monde ung haultz cas regarde,

Pource qu'elle est seule entre ung million. (Rigolot I: 163; Defaux II: 204) ${ }^{23}$

As he plays with the shared homophony between Ilyon, the ancient Greek name for Troy, and Lyon, the modern French marvel, Marot nevertheless does not locate the glories of the city in the ruins of Fourvière (the equivalent to Peylon). Rather, they are to be found "en une estant dedans sa garde" (v. 6, italics added), whose name he works into the subsequent verse: "Car qui la voit en esprit si galliarde / Plaisir y prend plus qu'à veoir Ilion" (vv. 7-8, italics also mine). A woman, a singular mind (seule entre ung million) held the merit of the Renaissance.

Short-lived as it may have initially been (ca. 1524-60), it was in Lyon and in the spirit of propagating free humanistic discourse and female verse - and not in the Pléiade's restrictive Paris - that the Renaissance in verse was announced. Marot opened a door and made a space for Jeanne 
Gaillarde, Jeanne Flore, Pernette du Guillet, Louise Labé and others that restrictive competing ideologies could not slam shut. Women were offered a space, in letters and society, which they had been previously denied. Present and with a voice in the salons of subsequent generations, women - even educated, bourgeois women - would dictate the direction of French letters for centuries as we ushered in the modern era.

\section{Notes}

1. Never officially convening as an organized poetic circle or group, the "Pléiade" (which Ronsard, emphasizing their desired revolutionary identity, originally termed the "Brigade") was essentially an oft-changing list of seven poets - mostly students from Paris' Collège de Coqueret or Collège de Boncourt (including a constant core of Ronsard and Du Bellay, as well as their professor the Hellenist Jean Dorat, fellow student of Greek Jean-Antoine de Baïf, the Burgundian aristocrat Pontus de Tyard, and interchanging Jodelle, Belleau, Pelletier du Mans, etc.) - corresponding to the seven stars of the Pleiades constellation, which self-proclaimed leader Ronsard deemed most directly embraced the poetic platform of innovation by imitation set out in Du Bellay's Deffence. (See Vignes, "L'éclat de la Pléiade," pp. 101-27; or, for a more in-depth explanation, see Henri Chamard's definitive four-volume Histoire de la Pléiade (Paris: Didier, 1939.)

2. In her "An Offensive Defense for a New Intellectual Elite," Margaret Ferguson reads Du Bellay's manifesto as a reactionary response to Thomas Sébillet's Art poétique français from one year earlier (1548), which lauds the late Marot as the superlative model of French poetic creation. In her assessment of the Deffence, the Pléiade's "chief target of attack is Clément Marot" (194).

3. Marot was incarcerated, despite his status as courtier, in the prisons of Châtelet, Chartres and the Conciergerie. His highly biographical poetic œuvre is likewise replete with various other references to being pursued by the Sorbonne and narrowly escaping to exile.

4. For a history of Marot and the invention of the French sonnet, consult the following (details in bibliography): Villey, "Marot et le premier sonnet français"; Mayer, "Le premier sonnet français"; Françon, "L'introduction du sonnet en France"; Rigolot, "The Sonnet"; Balsamo, "François Ier, Clément Marot et les origines du pétrarquisme français (1533-1539)," as well as my own article on the matter, "Clément Marot and the "invention' of the French Sonnet." The equation of Marot with his homophonic Roman forbear Maro (Publius Vergilius, i.e. Virgil) was 
an honor bestowed on him by the Neo-Latin poets of the Sodalitium lugdunense (who will appear again in the main body of the text) and a trope to which Marot often returned in his poetry; for a detailed account of the Marot/Maro poetic device (and the poet's self-fashioning alongside other Classical models), see Florian Preisig's section on "Virgile, Martial, Horace, Ovide et le Maro de France" (109-26) from his Clément Marot et les metamorphoses de l'auteur... - which also catalogues the various uses of the Marot/Maro trope in a useful appendix (159-63).

5. See also Grahame Castor's Pléiade Poetics (7-12) for a discussion of elitism in Renaissance poetic practices.

6. See Weber (109-16) and Castor (24-50) for discussion of theories of Divine Fury and the favorable conditions of inspiration.

7. That is, he was trained as a craftsman or artisan by his poet father. See bibliography for details on the Mantovani thesis.

8. While underlying the notion of being well-born and well-bred may already be a perceptible element of elitism - also present in the albeit more inclusionary "Cy n'entrez pas.../ Cy entrez..." poem (141-44), Rabelais tempers this with the fact that Alcofrybas Nasier addresses the work itself to the popular, tavern-frequenting element, his "Beuveurs tresillustres, et vous Verolez tresprecieux" (5), implying that a bourgeois class may well attain status in the ideal world of civitas he builds.

9. Many excellent articles exist detailing Lyon's openness to bourgeois, women and social others - most important are the following: Lucien Romier, "Lyon et le cosmopolitanisme"; Nathalie Zemon Davis' famous collection of essay Society and Culture in Early Modern France, the majority treating social reforms, poor relief and the status of women in $16^{\text {th }}$. century Lyon; François Rigolot, "Louise Labé et le "Climat Lyonnois"”; perhaps ironically, an early chapter from Mireille Huchon's infamous Louise Labé, une créature de papier (Droz, 2006) - a book that seeks to question the very existence of the bourgeois female poet - nevertheless admirably lays out the splendors and uniqueness of Renaissance Lyon, "Magnificences de Lyon et fureur poétique au milieu du siècle" (15-69); Michèle Clément and Janine Incardona's collection of essays $L$ 'émergence littéraire des femmes à Lyon à la Renaissance, 1520-1560; and, finally, Karen Simroth James' introduction to Lyonnais poet Pernette du Guillet's Complete Poems very clearly and succinctly lays out the social milieu and intellectual currents in Lyon that enabled the young female poet to create (1-73).

10. See Louis Bourgeois, Quand la cour de France vivait à Lyon $(23-44)$. 
11. Included as "Rondeaux" 19 and 20 in the Adolescence clémentine (1532), in Marot's Euvres of 1538, he changes the title from "Femme de grant sçavoir" to "Femme de bon sçavoir" (Rigolot, I: 552n.). In order to maintain consistency and clarity in my text, I have opted for modernized spellings in the titles, including for the name "Jehanne," rendered here as the modern "Jeanne". Once I begin my textual analysis below, however, I will hold to the original text. Also, having provided the page numbers from the two definitive critical editions of Marot (Defaux, 1990-93 and Rigolot, 2007-09), I will use the texts from the Rigolot edition and hereafter refer to the rondeaux simply as XIX (Marot's offering) and XX (Jeanne Gaillarde's response).

12. My presentation at the Sixteenth Century Society and Conference in October 2013 was entitled "The Marotic Rondeau: Gallic Verve in the Royal Female Court" (Caribe Hilton, San Juan, PR), a text version expanding upon which has been accepted for publication in a forthcoming edited volume, and discussed the links between the rondeau and women of the court.

13. See my aforementioned article "Clément Marot and the 'invention' of the French Sonnet" (biblio).

14. In Maurice Roy's critical edition of the CEuvres poétiques de Christine de Pisan (Paris: Firmin Didot, 1886) includes 69 rondeaux alongside a selection of ballads, lays and other medieval poetic forms.

15. As far as accurately rendering Christine de Pizan's $15^{\text {th }}$-century Middle French into intelligible prose for a modern audience, I find Rosalind Brown-Grant's English translation (London: Penguin, 1999) to remain truest to the original text and most guarded from the excessive poetic license of other translators.

16. In his "Voix de femmes, livres d'hommes," Daniel Martin cites a handful of other female poets in and around Lyon (Jacqueline de Stuard and Claude de Bectoz, most prominently, but also various others (90)) and, in "Documents nouveaux sur Jeanne Gaillarde et ses amis," V.-L. Saulnier details and hypothesizes on her poetic exchanges with other male poets of the time.

17. Among these poets is Nicolas Bourbon, to whom Marot would address a liminal poem in a later edition of the text.

18. Following the infamous Placard's Affair on 17-18 October 1534, Marot thought it wise, given his evangelical leanings, to leave France and seek refuge in Navarre and then Italy. He was allowed to return to the kingdom, via Lyon, should he publicly denounce his heretical actions of the past, which he did in December 1536. 
19. Having claimed the laurels of the "Concours des blasons," launched by Marot from Ferrara in 1535, the aspiring Lyonnais poet Maurice Scève could not help but feel a sense of rivalry with the elder established poet, as manifest in various poetic exchanges, particularly Epigrammes III: LIX “A Maurice Sceve, Lyonnois."

20. Two of his epigrams from the earlier second book, among others to individuals dwelling in Lyon, are addressed "A une Dame de Lyon" (II: XLIV) and "A deux Sœurs Lyonnaises" (II: XVI) and both are very generous in their praise of these women's artistic and intellectual capacities.

21. For example, my talk at the Sixteenth Century Society and Conference 2010 in Montreal: "Maurice Scève and the Ghost of Marot: The Gallic Influence in Lyrical Lyon" (14 October), as well as in an article currently under review.

22. Calvin would infamously go as far as to affix the label of plebeia meretrix [common street whore] to Louise Labé in a 1561 letter to a Lyonnais priest. Francis Higman translates Calvin's Latin passage on the necessity to eradicate adultery in Lyon into French as follows: "Car (un certain Lyonnais) a accoutoumé de réjouir ses hôtes qu'il veut bien festoyer de ce passe-temps, de leur introduire des femmes en habit d'homme. À quoi a souvent servi une paillarde assez renommée, à savoir la Belle Cordière" (465).

23. In one telling variation from Marot's 1538 collected CEuvres, verse nine was altered to read as follows: "Et de ce siècle un miracle regarde" (Rigolot I: 558n), suggesting that Marot perhaps recognized that the sixteenth century was introducing a new mentality to the world.

\section{Works Cited}

Balsamo, Jean. "François Ier, Clément Marot et les origines du pétrarquisme français (1533-1539)." Les poètes de la Renaissance et Pétrarque. Ed. Jean Balsamo. Genève: Droz, 2004. 35-51.

Bourgeois, Louis. Quand la cour de France vivait à Lyon, 1494-1551. Paris: Fayard, 1980.

Calvin, Jean. Cuvres. Ed. Francis Higman. Paris: Gallimard (Bibliothèque de la Pléiade), 2009.

Castor, Grahame. Pléiade Poetics: A Study in Sixteenth-Century Thought and Terminology. Cambridge: Cambridge UP, 1964.

Chamard, Henri. Histoire de la Pléiade. 4 Vols. Paris: Didier, 1939.

Clément, Michèle. "Comment un nouveau champ littéraire est créé à Lyon:

'En donnant lieu à la main féminine' (1530-1555)." L'émergence lit- 
tíraire des femmes à Lyon à la Renaissance, 1520-1560. Eds. Michèle

Clément and Janine Incardona. Saint-Etienne: PUF, 2008. 15-28.

Davis, Natalie Zemon. "Women in the Crafts in Sixteenth-Century Lyon."

Feminist Studies 8.1 (1982): 46-80.

---. Society and Culture in Early Modern France. Palo Alto: Stanford UP, 1975.

De Pizan, Christine. CEuvres poétiques de Christine de Pisan. Ed. Maurice Roy. Paris: Firmin Didot, 1886.

---. The Book of the City of Ladies. Trans. and Ed. Rosalind Brown-Grant.

London: Penguin Classics, 1999.

Du Bellay, Joachim. La Deffence, et illustration de la langue françoyse

\& L'Olive. Eds. Jean-Charles Monferran and Ernesta Caldarini.

Genève: Droz, 2007.

Du Guillet, Pernette. Complete Poems: A Bilingual Edition. Ed. Karen

Simroth James. Trans. Marta Rijn Finch. Toronto: CRRS (The Other

Voice in Early Modern Europe), 2010.

--.. Rymes (1545). Ed. Elise Rajchenbach. Genève: Droz, 2006.

Febvre, Lucien. Le Problème de l'incroyable au XVIe siècle: La religion de Rabelais. 1937. Paris: Albin Michel, 2003.

Ferguson, Margaret. "An Offensive Defense for a New Intellectual Elite."

A New History of French Literature. Ed. Denis Hollier. Cambridge, MA: Harvard UP, 1989. 194-98.

Françon, Marcel. "L'introduction du sonnet en France." Romance Philology 26 (1972): 62-67.

Geisendorf, Paul F. "Lyons and Geneva in the Sixteenth Century: The Fairs and Printing." French Humanism, 1470-1600. Ed. Werner L. Gundersheim. New York: Harper, 1969. 146-59.

Huchon, Mireille. Louise Labé, une créature de papier. Genève: Droz, 2006.

Hudson, Robert. "Clément Marot and the 'invention' of the French Sonnet." Anthropoetics 14.2 (2009): 1-33.

Labé, Louise. Euvres complètes. Ed. Enzo Giudici. Genève: Droz, 1981. Mantovani, Thierry. "Dans l'atelier du rhythmeur: contribution à l'étude des techniques de versification chez Jean et Clément Marot, Guillaume Cretin et André de la Vigne." Diss. Université de Lyon II-Lumière, 1995.

Marot, Clément. EEuvres completes. 2 Volumes. Ed. François Rigolot.

Paris: Flammarion, 2007-09.

--. Euvres complètes. 2 Volumes. Ed. Gérard Defaux. Paris: Bordas (Classiques Garnier), 1990-93. 
Martin, Daniel. "Voix de femmes, livres d'hommes. Autour de trois poétesses: Jeanne Gaillarde, Jacqueline de Stuard, Claude de Bectoz." L'émergence littéraire des femmes à Lyon à la Renaissance, 1520 1560. Eds. Michèle Clément and Janine Incardona. Saint-Etienne: PUF, 2008. 89-106.

Mayer, C. A. "Le premier sonnet français: Marot, Mellin de Saint-Gelais et Jean Bouchet." RHLF 67.3 (1967): 481-93.

Nauert, Jr., Charles G. Humanism and Culture in Renaissance Europe. Cambridge: Cambridge UP, 1995.

Preisig, Florian. Clément Marot et les métamorphoses de l'auteur à l'aube de la Renaissance. Genève: Droz, 2004.

Rabelais, François. Euvres complètes. Ed. Mireille Huchon. Paris: Gallimard (Bibliothèque de la Pléiade), 1994.

Rigolot, François. "Louise Labé and the 'Climat Lyonnois'." The French Review 71.3 (1998): 405-13.

--.. "The Sonnet." A New History of French Literature. Ed. Denis Hollier. Cambridge, MA: Harvard UP, 1989. 171-74.

---. Louise Labé Lyonnaise ou la Renaissance au féminin. Paris: Honoré Champion, 1997.

Romier, Lucien. "Lyon et le cosmopolitanisme au début de la Renaissance française." BHR 11 (1949): 28-42.

Saulnier, V.-L. "Document nouveaux sur Jeanne Gaillarde et ses amis: Clément Marot, Jacques Colin, Germain Colin." Bulletin de la Société Historique de Lyon 18 (1952): 79-100.

Sébillet, Thomas. "Art poétique français." 1548. Traités de poétique et de rhétorique de la Renaissance. Ed. Francis Goyet. Paris: Librairie générale française, 1990. 37-183.

Vignes, Jean. "L'éclat de la Pléiade: un programme ambitieux (15491578)." La poésie française du Moyen Age jusqu'à nos jours. Ed. Michel Jarrety. Paris: PUF, 1997. 101-14.

Villey, Pierre. "Marot et le premier sonnet français." RHLF 27 (1920): $538-47$.

Weber, Henri. La Création poétique au XVIe siècle en France. 1955. Paris: Nizet, 1994. 
